\title{
THE EFFECT OF SOY FLOUR ON COOKIE QUALITY
}

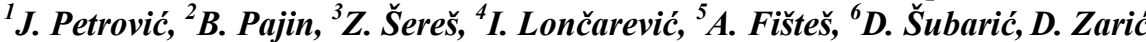

${ }^{1}$ Department of Carbohydrate Food Engineering, Faculty of Technology, University of Novi Sad, 21000, Bul. Cara Lazara 1, 21000 Novi Sad, Serbia, e-mail: jovana@tf.uns.ac.rs

${ }^{2}$ Department of Carbohydrate Food Engineering, Faculty of Technology, University of Novi Sad, 21000, Bul. Cara Lazara 1, 21000 Novi Sad, Serbia, e-mail: pajinb@tf.uns.ac.rs

${ }^{3}$ Department of Carbohydrate Food Engineering, Faculty of Technology, University of Novi Sad, 21000, Bul. Cara Lazara 1, 21000 Novi Sad, Serbia, e-mail: zitas@tf.uns.ac.rs

${ }^{4}$ Department of Carbohydrate Food Engineering, Faculty of Technology, University of Novi Sad, 21000, Bul. Cara Lazara 1, 21000 Novi Sad, Serbia, e-mail: ivana.radujko@tf.uns.ac.rs

${ }^{5}$ Department of Carbohydrate Food Engineering, Faculty of Technology, University of Novi Sad, 21000, Bul. Cara Lazara 1, 21000 Novi Sad, Serbia, e-mail: fistes@tf.uns.ac.rs

${ }^{6}$ Department of Food Technology/Subdepartment of Carbohydrate Technology, Faculty of Food Technology, University of Josip Juraj Strossmayer, Trg Svetog Trojstva 3, 31000 Osijek, Croatia, e-mail: Drago.Subaric@ptfos.hr

${ }^{3}$ Ihis Techno Experts doo, research development center, 11000 Belgrade, Serbia, e-mail: Danica.zaric@ihis-nutricionizam.rs

\begin{abstract}
Cookies are a popular confectionery product with a unique texture and taste, long shelf life and a relatively cheap price; therefore, it is a widespread snack among people of all generations. Nevertheless, cookies are usually made of wheat flour and most formulations are highly caloric and have a low fiber content. Soy flour is an excellent source of proteins, fibers, vitamins and minerals and it is being considered as a great supplement to wheat flour because it increases nutritive characteristics of the final product. By their digestibility and amino acid content, soy proteins are very similar to proteins derived from animals. They also contain many essential amino acids, which are deficient in most of the cereals. The purpose of this work was to determine the effect of soy flour on quality of cookies. Wheat flour was supplemented with $35 \%$ of soy flour (full-fat toasted, low-fat toasted, defatted lightly toasted, toasted and soy protein concentrate). The supplementation of wheat flour with soy flour had affected nutritive value and sensory characteristics of cookies.
\end{abstract}

Keywords: soy-flour, cookies, chemical analysis, sensory characteristics

\section{INTRODUCTION}

Cookies are a popular confectionery product with a unique texture and taste, long shelf life and a relatively cheap price; therefore, it is a widespread snack among people of all generations. Nevertheless, cookies are usually made out of wheat flour and most formulations are highly caloric and have a low fiber content. Soy flour is an excellent source of proteins, fibers, vitamins and minerals and it is being considered as a great supplement to wheat flour because it increases nutritive characteristics of the final product. Soy is being used both for human and animal nutrition because of its great nutritive characteristics, relatively cheap price, high quality and quantity of proteins and oil, as well as functional properties which contribute to the development of different foods for human nutrition [1]. By their digestibility and amino acid content, soy proteins are very similar to proteins derived from animals. They also contain many essential amino acids, which are deficient in most of the cereals. However, Raw Soybean Seed Meal (RSSM) contain high levels of anti-nutritional factors (ANFs), such as protease trypsininhibitors, lipase inhibitors, goitrogens, and hemagglutins, which must be deactivated by proper heat treatmentprior to inclusion in animal and human diets [1]. As improvements in nutritive value can only be considered successful if a product with visual, textural and organoleptic qualities acceptable to the consumer is produced, functional properties of various protein supplements have been the focus of interest of many researchers and technologists. Although many different plant proteins have been studied and used, soy protein still remains the most widely investigated supplement [2].

In ref. [3] researcers examined the development of the dough obtained of mixtures of wheat and soybean flour $(12 \%)$ and found that it takes more time for the development of the dough in relation to the dough produced only with wheat flour, as well as to thereby absorb a greater amount of water . It was also found 
that replacement of wheat flour, soybean significantly increases the protein content in the final product . It has been proven that soy flour prolongs the shelf life of bread, improves structure and increases the consistency and nutritional quality of bread. It was also found that bread with soy flour has pleasant taste. Biscuits made from a mixture of wheat flour and soybean flour (30:60) showed better nutritional properties and improved color of biscuit made from pure wheat flour [4].

Reference [5] have examined how much of the wheat flour in making tortillas can be replaced with soy flour and proven that replacing $30 \%$ of wheat flour with soy flour can be obtained tasty and a good technology product. Reference [1] contains evaluation of gluten-free spaghetti with soy flour from a mixture of rice and soy flour. This combination gives flour dough beautiful colors that does not stick and which has greater firmness than the dough made from pure rice flour.

Unfortunately, a complete replacement of wheat flour with soy flour is not possible in a number of products due to specific taste and poor texture of soy products, but it is proven that the addition of hydroxypropyl methylcellulose improves the characteristics of gluten-free bread [7]. The addition of soy flour in food products increases the content of crude protein, ash and crude fiber and moisture content significantly decreased [8]. Addition of high-protein soybean flour also reduces the amount of carbohydrates in the products, which makes them more desirable low calorie functional products [9].

The purpose of this work was to determine the effect of soy flour on the cookies quality. Wheat flour was supplemented with $35 \%$ of soy flour (full-fat toasted, low-fat toasted, moderately toasted, toasted and soy protein concentrate). The supplementation of wheat flour with soy flour had affected nutritive value and sensory characteristics of cookies.

\section{MATERIALS}

Wheat flour for cookies and biscuits were obtained from milling company "Ratar", Pančevo, Serbia. Soy flour: full-fat toasted, low-fat toasted, defatted lightly toasted, toasted and soy protein concentrate were obtained from "Sojaprotein" AD Bečej, Serbia. Other ingredients for cookie making - vegetable fat, salt, sodium bicarbonate, ammonium bicarbonate and powdered sugar were purchased in a local food store.

\section{METHODS}

\subsection{Preparation of cookies}

Blends of wheat flour with different type of soy flour, containing $35 \%$ of soy flour, on a replacement basis, were prepared using the F-6-RVC agitator (Forberg International AS, Norway). Control cookie sample was prepared using wheat flour without soy flour. Cookies dough was prepared according to the following formula: flour (i.e. flour blend) $200.00 \mathrm{~g}$, vegetable fat $42.00 \mathrm{~g}$, sugar $70.00 \mathrm{~g}, \mathrm{NaHCO}_{3} 0.6 \mathrm{~g}, \mathrm{NH}_{4} \mathrm{HCO}_{3}$ $0.4 \mathrm{~g}$ and $\mathrm{NaCl} 1.1 \mathrm{~g}$. The measured amount of flour was mixed in a mixer for $0.5 \mathrm{~min}$, and after the addition of the total amount of fat and powdered sugar, the mixing was continued for $5.5 \mathrm{~min}$ at low speed $\left(60 \mathrm{~min}^{-1}\right)$. All other components dissolved in distilled water were added into the mixer, the mixer closed and the dough mixed for $15 \mathrm{~min}$. The amount of water was calculated in relation to the water content of the flour blends in order to obtain dough samples with $24 \%$ moisture content. After mixing, the dough samples were processed by sheeting it between two cylinders of laminator (Marchand LA4-500, Materiel modern marchand, Rueil - Malmaison, France). The gap settings between the cylinders were: $14 \mathrm{~mm}, 10 \mathrm{~mm}, 7$ $\mathrm{mm}$ and $5 \mathrm{~mm}$, with $15 \mathrm{~s}$ resting period between each passage. Consequently, the dough was cut using a stainless mould and prepared cookie dough was baked for $15 \mathrm{~min}$ at $230^{\circ} \mathrm{C}$ in a laboratory oven followed by cooling (2h) and packaging (in high-density polyethylene). Cookie sample with defatted lightly toasted soy flour was marked as OUT, with defatted toasted as OT, with lowfat toasted as MT, with fullfat toasted as PT and with soybean protein concentrate as SPK (Tab. 1). 
Table 1. Evaluated cookie samples

\begin{tabular}{|c|c|c|c|c|c|c|}
\hline Sample & Control & PT & MT & OT & OUT & SPK \\
\hline Flour type & $\begin{array}{c}100 \% \\
\text { wheat flour }\end{array}$ & $\begin{array}{c}35 \% \text { fullfat } \\
\text { toasted, 65\% } \\
\text { wheat flour }\end{array}$ & $\begin{array}{c}35 \% \text { lowfat } \\
\text { toasted, 65\% } \\
\text { wheat flour }\end{array}$ & $\begin{array}{c}35 \% \\
\text { defatted } \\
\text { toasted, } \\
65 \% \text { wheat } \\
\text { flour }\end{array}$ & $\begin{array}{c}35 \% \text { defatted } \\
\text { lightly } \\
\text { toasted, 65\% } \\
\text { wheat flour }\end{array}$ & $\begin{array}{c}35 \% \\
\text { soybean } \\
\text { protein } \\
\text { concentrate, } \\
65 \% \text { wheat } \\
\text { flour }\end{array}$ \\
\hline
\end{tabular}

\subsection{Determination of chemical composition}

Moisture, protein, fat, fiber and ash contents of wheat flour, soy flour and cookies based on dry weight were determined according to the method described in the [10]. Total carbohydrates were calculated by difference.

\subsection{Alkaline Water Retention Capacity (AWRC)}

The AWRC of the wheat flour and blands of wheat flour and different type of soy flour were determined according to the standard method [11].

\subsection{Sensory Analysis}

Cookie samples were evaluated by a panel of 25 consumers, $24 \mathrm{~h}$ after baking. Panelist scored the cookie characteristics (color, hardness chewiness, odor, taste, aftertaste and overall acceptability) using 7 - point hedonic scale $(1$ - dislike extremely, 2 - dislike very much, 3 - dislike moderately 4 - neither like nor dislike, 5 - like moderately, 6 - like very much, 7 - like extremely) [12]. Cookie samples were served to panelists on white plastic plates labeled with three-digit codes from a random number table. Panelists were asked to swallow samples and to rinse their mouths with water between samples.

\section{RESULTS AND DISCUSSION}

\subsection{Chemical analysis}

Comparison of the chemical composition of wheat flour and different types of soy flour are shown in Tab. 2.

Table 2. Chemical composition of wheat flour and different types of soy flour

\begin{tabular}{|l|l|l|l|l|l|l|}
\hline Flour & $100 \%$ wheat & $100 \%$ OUT & $100 \%$ OT & $100 \%$ MT & $100 \%$ PT & $100 \%$ SPK \\
\hline Moisture (\%) & 10.83 & 5.07 & 4.59 & 3.94 & 4.92 & 4.25 \\
\hline Protein (\%) & 10.04 & 35.99 & 40.10 & 34.74 & 25.52 & 53.83 \\
\hline Fat (\%) & 0.95 & 0.62 & 0.83 & 5.86 & 23.55 & 0.38 \\
\hline Ash (\%) & 0.54 & 6.69 & 6.79 & 6.45 & 3.54 & 6.57 \\
\hline Fiber (\%) & 3.80 & 25.91 & 22.66 & 25.07 & 26.83 & 26.58 \\
\hline Carbohydrats (\%) & 77.64 & 51.63 & 47.69 & 49.01 & 42.47 & 34.97 \\
\hline
\end{tabular}

On the basis of chemical analysis, it can be seen that the wheat flour has a lower content of proteins (only $10.04 \%$ ) relative to all 5 types of examined soy flour (from 25.52 to $53.83 \%$ ). Withal, soy flour has a higher mineral content (about 6\%) and fiber (as much as 20\%) of wheat flour, while proportion of 
carbohydrates is smaller (even twice lower at SPK). There are also differences in the chemical composition among the various types of soy flour (PT and MT are characterized by a higher content of fat $(23.55 \%$ and $5.86 \%$ relative to the OUT, SPK and OT $(0.62 \%, 0.83 \%$ and $038 \%))$, and SPK has the largest share of protein $(53.83 \%))$.

\subsection{Alkaline water retention capacity}

Tab. 3 shows the results gained by the analysis of AWRC of wheat flour and wheat flour-soy flour blends in alkali. Blends of soy and wheat flour had higher AWRC values comparing with wheat flour.

Table 3. Alkaline water retention capacity (AWRC) of the wheat flour and wheat flour-soy flour blends

\begin{tabular}{|c|c|}
\hline Sample & AWRC (\%) \\
\hline Wheat flour & 67.74 \\
\hline $35 \%$ OUT & 86.62 \\
\hline $35 \%$ OT & 103.61 \\
\hline $35 \%$ MT & 102.57 \\
\hline $35 \%$ PT & 94.4 \\
\hline $35 \%$ SPK & 107.09 \\
\hline
\end{tabular}

Such high AWRC values (86-107\%) are the result of a high content of protein and fiber in soy flour, which are capable for binding the water. AWRC values of soy flour are in accordance with the results of chemical analysis for the determination of protein and fiber (Tab. 2), where it can be seen that soy protein concentrate has the highest protein content $(53.83 \%$ ), and a mixture of $35 \%$ SPK has the highest AWRC value (107\%), while the lowest values AWRC have blands with OUT and MT (86.62 and 94.4\%), which have the smallest protein content (35.99\% and 25.52\%). The results are in accordance with research of [3], who also came to the conclusion that a mixture of wheat and soybean flour absorbs a greater amount of water compared to wheat flour.

\subsection{Chemical caracteristics of cookies}

In accordance with differences in the chemical composition of different types of wheat and soybean flour (Tab. 2), there are significant differences in the chemical composition of the final product. In Tab. 4 it can be seen that the cookies containing soy flour were significantly richer in protein (two and even three times more (SPK)). Concurrently, there was increased content of minerals and fiber, on the other hand reduced the carbohydrate content of $74.80 \%$ to $63.62 \%$, which could be important for people with diabetes.

Table 4. The influence of soy flour on cookies chemical characteristics

\begin{tabular}{|l|c|c|c|c|c|c|}
\hline Sample & Control & OUT & OT & MT & PT & SPK \\
\hline Moisture (\%) & 5.24 & 2.28 & 1.99 & 2.19 & 1.20 & 4.48 \\
\hline Protein (\%) & 5.79 & 13.73 & 13.89 & 12.24 & 11.58 & 16.52 \\
\hline Fat (\%) & 13.55 & 13.51 & 18.10 & 14.56 & 13.73 & 12.86 \\
\hline Ash (\%) & 0.62 & 1.87 & 1.60 & 1.80 & 1.90 & 1.98 \\
\hline Fiber (\%) & 4.57 & 5.30 & 5.29 & 5.33 & 4.27 & 6.18 \\
\hline Carbohydrats (\%) & 74.80 & 69.15 & 68.49 & 69.21 & 67.52 & 63.62 \\
\hline
\end{tabular}




\subsection{Sensory analysis}

According to the results of sensory analysis, which are shown in Tab. 5, it can be seen that the panelists have given higher color score for cookie with soy flour, so the addition of soy flour positivelly influences cookies color. Addition of soy flour generally influenced the creation of a darker cookies color, while the highest browning caused toasted soy flour with a lower fat content (OT). It is known that Maillard reactions play an important role in the formation of colored baked goods. Darker color of cookies with soy flour is the result of a higher protein content (free amino acids such as lysine) in soybean flour which causing intensively Maillard reaction [13]. Reference. [4] showed that the biscuits made from a mixture of wheat and soybean flour in which there were more than $60 \%$ soy flour had a better color than biscuits made from pure wheat flour. However, cookie samples with soy flour had a wrinkled surface with visible cracks. The negative impact soy flour had on the hardness and chewiness. Samples with soy flour were firm and brittle and had rough and compact structure. Also, these samples were slow in softening during chewing. Cookie hardness is highly dependent on the moisture content in the dough. AWRC values of soy flour are greater than the value of wheat (Tab. 3), which means that soy flour have a higher absorption of water during the mixing procedure, due to higher content of protein and fiber, which results in increased strength of the dough and thus in hardness of cookies with soy flour. The best structure and minimum hardness had a sample with PT soy flour. Although proteins and fibers absorb water causing cookie hardening, higher content of fat in PT soy flour can compensate for hardness.

Table 5. Sensory analysis of cookie samples

\begin{tabular}{|l|c|c|c|c|c|c|}
\hline \multicolumn{1}{|c|}{ Sample } & Control & OUT & OT & MT & PT & SPK \\
\hline Color & 4.0 & 4.0 & 6.0 & 6.0 & 6.0 & 4.0 \\
\hline Hardness & 6.0 & 3.0 & 2.0 & 3.0 & 4.0 & 5.0 \\
\hline Chewiness & 6.0 & 3.0 & 3.0 & 4.0 & 5.0 & 6.0 \\
\hline Odor & 6.0 & 5.0 & 6.0 & 6.0 & 6.0 & 4.0 \\
\hline Taste & 7.0 & 5.0 & 5.0 & 5.0 & 6.0 & 4.0 \\
\hline Aftertaste & 5.0 & 4.0 & 4.0 & 4.0 & 6.0 & 4.0 \\
\hline Overall acceptability & 6.0 & 4.0 & 5.0 & 5.0 & 6.0 & 5.0 \\
\hline
\end{tabular}

Scores for taste, odor and overall acceptability of cookies with soy flour are close to the values of the control sample, which means that the addition of soy flour did not have effect on deterioration of these characteristics. Taste and smell were inherent to the nature of the product. The samples with the addition of soy flour had residual taste after chewing, which panelists liked and did not affect the reduction in score for taste and overall acceptability of cookies. The highest scores, closest to the control sample had cookie sample with the addition of PT soy flour. The greatest impact on the deterioration of the sensory evaluation had addition of OT soy flour.

\section{CONCLUSION}

Soy flour is nutrition valuable product rich in bioactive compounds. It can be used for increasing nutritional value of cookies. Addition of soy flour increased protein, fiber and mineral content of cookies, while carbohydrate content was reduced from $74.80 \%$ to $63.62 \%$. Soy flour addition had significant influence on cookie color. Cookie surface became darker and number of cracks on cookie surface increased. The negative impact soy flour had on the hardness and chewiness. The addition of soy flour did not have effect on deterioration of taste, odor and overall acceptability of cookies. 


\section{ACKNOWLEDGEMENT}

This work has been fully supported by Croatian Science Foundation under the project 1321.

\section{REFERENCES}

[1] N. Siulapwa, A. Mwambungu, Nutritional Value of Differently Processed Soybean Seeds, The Indian Journal of Nutrition and Dietetics, 52 (1), (2015), pp. 45-56.

[2] S. S. Chen, V. F. Rasper, Functionality of soy proteins in wheat flour/soy isolate doughs. I. Characterization of isolates prepared using different isolation procedures. Canadian Institute of Food Science and Technology Journal, 15 (3), (1982), pp. 203-210.

[3] T. L.Traynham, Evaluation of extruded-expelled low-fat soybean flour in flour blends and the effects on bread and dough development, $\mathrm{PhD}$ dissertation, 2006

[4] J. I. Okoye, A. C. Nkwocha, A. E. Ogbonnaya, Production, proximate composition and consumer acceptability of biscuits from wheat/soybean flour blends, Continental J. Food Science and Technology, 2, (2008), pp. 6-13.

[5] J. E. Romanchik-Cerpovicz, K. E. Braswell, P. F. Cerpovicz, Effect of Flour Type on the Physical and Sensory Characteristics of Tortillas Fortified with Soy, Journal of the Academy of Nutrition and Dietetics, 9 (14), (2014), p. A61.

[6] 20. P. Sereewat, C. Suthipinittham, S. Sumathaluk, Cooking properties and sensory acceptability of spaghetti made from rice flour and defatted soy flour, LWT - Food Science and Technology 60, (2015), pp. 1061-1067.

[7] J. Kim, I. Choi, W. Shin, Y., Kim Effects of HPMC (Hydroxypropyl methylcellulose) on oil uptake and texture of gluten-free soy donut, LWT -Food Science and Technology, 62 (1), (2015), pp. 620-627.

[8] M. I. Khan, F. M. Anjum, T. Zahoor i sar. Nutritional characterization of the Wheat-Soy unleavened flat bread by rat bioassay, Sarhad J. Agric., 25 (1), (2009), pp. 73-80.

[9] M. Singh, A. Mohamed Influence of gluten-soy protein blends on the quality of reduced carbohydrates cookies, LWT-Food Science and Technology, 40 (2), (2007), pp. 353-360.

[10] AACC, Approved Methods of the American Association of Cereal Chemists, American Association of Cereal Chemists, (2000), St. Paul, MN.

[11] AACC, Approved Methods of the American Association of Cereal Chemists, American Association of Cereal Chemists, (AACC method 56-10, St. Paul, MN., 2000

[12] ISO 4121. Sensory analysis - Methodology - Evaluation of food product by methods of using scales, International Organization for Standardization, 2002)

[13] S. Perez, E. Matta, C. Osella, Effect of soy flour and whey protein concentrate on cookie color, LWT Food Science and Technology, 50 (1), (2013), pp. 120-125. 